\title{
Mind the gap: Mapping Variation between \\ National and Local Clinical Practice Guidelines for Acute Paediatric Asthma from the United Kingdom and the Netherlands
}

Charlotte Koldeweij, ${ }^{1,2}$ Jonathan Clarke, ${ }^{3,4}$ Carmen Rodriguez Gonzalvez, ${ }^{2}$ Joppe Nijman, ${ }^{5}$ Ruchi Sinha, ${ }^{6}$ Ian Maconochie, ${ }^{7}$ Nicholas Appelbaum ${ }^{2,3}$

${ }^{1}$ Radboud Institute for Health Sciences, Radboud University Medical Center, Nijmegen, The Netherlands

${ }^{2}$ Helix Centre for Design in Healthcare, Imperial College London, London, UK

${ }^{3}$ Department of Surgery and Cancer, Imperial College London, London, UK

${ }^{4}$ Centre for Mathematics of Precision Healthcare, Imperial College London, London, UK

${ }^{5}$ Department of Pediatric Intensive Care, University Medical Center Utrecht, Utrecht, The

Netherlands

${ }^{6}$ Department of Paediatric Intensive Care, Division of Women and Children's

Services, Imperial College Healthcare NHS Trust, London, London, UK

${ }^{7}$ Centre for Paediatrics and Child Health, Imperial College Healthcare NHS Trust, London, London, UK

\section{Corresponding Author}

Charlotte Koldeweij, MSc, MD

Department of Pharmacology and Toxicology

Radboud Institute for Health Sciences

Radboud University Medical Center, Nijmegen, The Netherlands

charlotte.koldeweij@radboudumc.nl

\section{Key words}

Clinical practice guideline, variability, paediatrics, asthma, evidence-based medicine 


\section{Abstract}

Background: Clinical practice guidelines (CPGs) aim to standardize clinical care. Increasingly, hospitals rely on locally produced guidelines alongside national guidance. This study examines variation between national and local CPGs, using the example of acute paediatric asthma guidance from the United Kingdom and the Netherlands.

Methods: Fifteen British and Dutch local CPGs were collected with the matching national guidance for the management of acute asthma in children under 18 years old. The drug sequences, routes and methods of administration recommended for patients with severe asthma and the tone of recommendation across both types of CPGs were schematically represented. Deviations from national guidance were measured. Variation in recommended doses of intravenous salbutamol was examined.

Results: British and Dutch national CPGs differed in the recommended drug choices, sequences, routes and methods of administration for severe asthma. Dutch national guidance was more rigidly defined. Local British CPGs diverged from national guidance for $23 \%$ of their recommended interventions compared to $8 \%$ for Dutch local CPGs. Five British local guidelines and two Dutch local guidelines differed from national guidance for multiple treatment steps. Variation in second-line recommendations was greater than for first-line recommendations across local CPGs from both countries. Recommended starting doses for salbutamol infusions varied by more than tenfold.

Conclusions: Local CPGs for the management of severe acute paediatric asthma featured substantial variation and frequently diverged from national guidance. Although limited to one condition, this study suggests that unmeasured variation across local CPGs may contribute to variation of care more broadly, with possible effects on healthcare quality. 


\section{Introduction}

The increasing volume of new clinical evidence hinders the ability of individual clinicians to incorporate large amounts of constantly updated information into their decision-making (1). Clinical practice guidelines (CPGs) are documents that systematically distil medical evidence into treatment recommendations to inform patient care $(2,3)$. CPGs support the provision of evidence-based medicine and aim to optimize the quality and cost-effectiveness of care $(1,4-6)$. CPGs are produced by numerous leading clinical institutions, including professional bodies and national societies like the National Institute for Health and Care Excellence (NICE) in the United Kingdom (UK) and the Dutch Federation of Medical Specialists (7-9). These organisations systematically review the scientific literature, condensing the best available evidence into practice-oriented recommendations for various conditions $(4,10-$ 13). Expert opinion and consensus judgment may be used in the absence of conclusive evidence (10).

Despite their stated goal of standardising the quality of clinical care (3), CPGs are not a matter 'of one size fits all'(14). It may not always be possible for clinicians at a given hospital to adopt national recommendations without adaptation to their local resources and needs, for example, differences in the availability of medications, various levels of local expertise or financial constraints $(12,14)$. In contrast to the well-defined methodologies used to design national CPGs, the production of local CPGs remains a largely ad-hoc process, driven by small groups of clinicians with various levels of familiarity with guideline development $(10,15)$. In addition to drawing on national CPGs, local CPGs may incorporate alternative 
sources of information, including locally available expert opinion and scientific literature published more recently than that incorporated in national CPGs $(1,16)$.

Although national CPGs and their locally adapted counterparts have become a staple of dayto-day care, variation in clinical practice continues to undermine healthcare outcomes $(17,18)$. An example of this is provided by the management of acute paediatric asthma (APA). Asthma is the most common chronic paediatric condition in the UK and the Netherlands $(19,20)$. There are approximately 25,000 annual emergency hospital admissions for APA in the UK (20). Despite APA being extensively covered in national and local clinical guidance (21-23), variation in the emergency clinical management of APA is widespread $(20,24-26)$. Significant variation in regional mortality from asthma, including APA, has been reported in recent years (27). Variation in clinical practice has been related to differences in CPGs, including those produced by individual hospitals (28-30). The nature and extent of local CPG variation, however, remains poorly understood. This study examines variation in the treatment recommendations for severe APA outlined in national guidance from the UK and the Netherlands and by a sample of local CPGs from British and Dutch hospitals.

\section{Methods}

\section{Guideline and data sampling}

National guidelines on APA produced by the British Thoracic Society/Scottish Intercollegiate Guideline Network (BTS/SIGN) in 2019 and the Dutch Paediatric Society (NVK) in 2012 were collected $(21,23)$. A convenience sample of local CPGs for APA management were obtained between 1 January and 1 February 2019 from Dutch and British tertiary-level hospitals. Local CPGs were retrieved online from hospital websites where available, or were obtained from 
medRxiv preprint doi: https://doi.org/10.1101/2021.09.20.21263735; this version posted September 23, 2021. The copyright holder for this preprint (which was not certified by peer review) is the author/funder, who has granted medRxiv a license to display the preprint in perpetuity.

It is made available under a CC-BY 4.0 International license .

clinicians working at each hospital. The most recent version of each local CPG was used. CPG recommendations were subdivided according to the age of the patient, to the clinical severity of APA at presentation and according to a patient's response to treatment. Treatments recommended in children two to eighteen years old were examined. The criteria outlined by each CPG to assess asthma severity at presentaton were collected. Pharmacological interventions recommended for managing patients with the most severe form of asthma at presentation and by a lack of response to consecutive treatments were examined. Hereafter, this is referred to as the 'most severe' treatment pathway. For each CPG, the dose, route (e.g. intravenous) and method (e.g. a bolus) of administration of each recommended drug was extracted, alongside the order in which it was suggested to be administered. The tone of each recommendation was noted and categorized as either mandatory ('give') or optional ('consider giving').

\section{Variation in drug choice, sequence and tone}

Differences in drug choice, sequence and route of administration across the sampled local CPG treatment pathways were measured using the relevant national $C P G$ as a reference. Local CPGs were awarded one point at each step if they recommended a drug type or an administration route that differed from their respective national CPG at that position or if additional alternatives were offered. Differences in methods of administration or in the tone of recommendation were not scored. Differences in drug choice, sequence, route and method of administration and tone of recommendation across the sampled treatment pathways were also represented in a common schematic diagram. Design idioms were borrowed from familiar urban transport maps. Each guideline was represented as a single line featuring the sequence of drugs recommended for a patient with most severe APA. 
Where a guideline offered clinicians the choice between two drugs with no distinct preference, both choices were represented. Drugs recommended for treating comorbidities, differential diagnoses or side effects resulting from the primary APA treatment were not represented.

\section{Variation in drug dosage}

Beyond differences in recommended drug choice, sequence and tone of recommendation, variation may also exist in medication dosing. For APA, this has, for instance, been shown to be the case for continuous salbutamol infusions(31). As a case study, the upper and lower limits of recommended salbutamol infusion dose ranges were compared across the sample.

\section{Results}

\section{Guideline description}

Of the sampled local CPGs, seven came from British tertiary-level hospitals and seven from Dutch tertiary-level hospitals, including two CPGs from different units of the same Dutch hospital (NL1a and NL1b). One additional Dutch hospital had no local CPG and used national (NVK) guidance (NL5). The basic characteristics of the sampled CPGs and the criteria used by each CPG to characterise APA severity at presentation are shown in Table 1 . All CPGs stratified patients into two ('moderate' and 'severe') or three ('moderate', 'severe', and 'life-threatening') categories. In line with NVK guidance, most local Dutch CPGs distinguished two groups at presentation using a 94\% oxygen saturation (SpO2) threshold. Local British CPGs mostly aligned with British national (BTS/SIGN) guidance, and defined 
medRxiv preprint doi: https://doi.org/10.1101/2021.09.20.21263735; this version posted September 23, 2021. The copyright holder for this preprint (which was not certified by peer review) is the author/funder, who has granted medRxiv a license to display the preprint in perpetuity.

It is made available under a CC-BY 4.0 International license .

three groups based on a 92\% SpO2 threshold alongside other diagnostic parameters including the presence of signs of life-threatening APA. 
Table 1. Description of sampled acute paediatric asthma CPGs from the UK and the Netherlands. APA: acute paediatric asthma, NL: Netherlands, PEF: peak expiratory flow, PICU: Paediatric Intensive Care Unit, SpO2: oxygen saturation. ${ }^{1}$ Applicable for children above 5 years.

\begin{tabular}{|c|c|c|c|c|c|c|c|c|}
\hline Guideline & $\begin{array}{c}\text { Last } \\
\text { updated }\end{array}$ & $\begin{array}{c}\text { Scale of } \\
\text { application }\end{array}$ & Setting & $\begin{array}{l}\text { Online } \\
\text { access }\end{array}$ & Authors & $\begin{array}{l}\text { Description } \\
\text { of methods }\end{array}$ & $\begin{array}{l}\text { Number of } \\
\text { stratified } \\
\text { patient groups } \\
\text { at presentation }\end{array}$ & $\begin{array}{l}\text { Assessment parameters for most severe } \\
\text { APA at presentation }\end{array}$ \\
\hline BTS/SIGN & 2019 & National & $\begin{array}{l}\text { Hospital } \\
\text { including PICU }\end{array}$ & Yes & $\begin{array}{l}\text { Paediatricians, respiratory } \\
\text { consultants, pharmacists, } \\
\text { researchers, nurse specialists \& } \\
\text { practictioners }\end{array}$ & Yes & Three & $\begin{array}{l}\text { spO } 2<92 \% \text { plus any of the following: PEF }< \\
33 \% \text { of best or predicted, }{ }^{1} \text { silent chest, } \\
\text { cyanosis, poor respiratory effort, agitation, } \\
\text { confusion }\end{array}$ \\
\hline NVK & 2012 & National & $\begin{array}{l}\text { Hospital, not } \\
\text { specified }\end{array}$ & Yes & $\begin{array}{l}\text { Paediatricians, paediatric } \\
\text { respiratory consultants }\end{array}$ & Yes & Two $^{1}$ & $\mathrm{spO} 2 \leq 94 \%$ \\
\hline UK1 & 2014 & Local & $\begin{array}{l}\text { Hospital } \\
\text { excluding PICU }\end{array}$ & No & $\begin{array}{l}\text { Asthma Steering Group, not } \\
\text { further specified }\end{array}$ & No & Three & $\begin{array}{l}\text { spO } 2<92 \% \text { plus any of the following: PEF }< \\
33 \% \text { of best or predicted value } 1 \text { silent chest } \\
\text { and/or cyanosis, poor respiratory effort, } \\
\text { altered consciouness }\end{array}$ \\
\hline UK2 & 2016 & Local & Not specified & No & Paediatrician & No & Three & $\begin{array}{l}\text { spO } 2<92 \% \text { plus any of the following: PEF }< \\
33 \% \text { of best or predicted value, }{ }^{1} \text { silent } \\
\text { chest, cyanosis, poor respiratory effort, } \\
\text { agitation or exhaustion, altered } \\
\text { consciousness }\end{array}$ \\
\hline UK3 & 2018 & Local & $\begin{array}{l}\text { Ward excluding } \\
\text { PICU }\end{array}$ & Yes & $\begin{array}{l}\text { Paediatric respiratory consultant, } \\
\text { paediatrician, clinical pharmacist }\end{array}$ & Yes & Three & $\begin{array}{l}\text { Any of the following: spO } 2<92 \% \text {, silent } \\
\text { chest, cyanosis, poor respiratory effort, } \\
\text { fatigue or exhaustion, agitation or reduced } \\
\text { consciousness }\end{array}$ \\
\hline UK4 & 2015 & Local & Not specified & No & $\begin{array}{l}\text { Paediatric respiratory consultant, } \\
\text { paediatrician, paediatric } \\
\text { intensive care consultant, } \\
\text { paediatric medical pharmacist }\end{array}$ & Yes & Three & $\begin{array}{l}\text { spO2 }<92 \% \text { plus any of the following: silent } \\
\text { chest, cyanosis, poor respiratory effort, } \\
\text { agitation or altered consciousness, } \\
\text { exhaustion, increased pCO } 2 \text { or hypotension }{ }^{3}\end{array}$ \\
\hline UK5 & 2017 & Local & $\begin{array}{l}\text { Hospital } \\
\text { including PICU }\end{array}$ & No & $\begin{array}{l}\text { Paediatric respiratory consultant, } \\
\text { paediatrician, paediatric medical } \\
\text { pharmacist }\end{array}$ & Yes & Three & $\begin{array}{l}\text { Any of the following: } \mathrm{spO} 2<92 \%, \mathrm{PEF}<33 \% \\
\text { of best or predicted value, }{ }^{1} \text { silent chest, } \\
\text { poor respiratory effort, agitation or altered } \\
\text { consciousness, heart rate } \geq 140 / \mathrm{min}(2-5 \\
\text { years) or }>125 / \mathrm{min} \text { ( } \geq 5 \text { years) }\end{array}$ \\
\hline
\end{tabular}




\begin{tabular}{|c|c|c|c|c|c|c|c|c|}
\hline UK6 & 2017 & Local & $\begin{array}{l}\text { Hospital, } \\
\text { excluding PICU }\end{array}$ & Yes & $\begin{array}{l}\text { Paediatric respiratory consultant, } \\
\text { paediatricians, senior staff nurse }\end{array}$ & No & Two $^{1}$ & $\begin{array}{l}\text { Any of the following: spO } 2<92 \%, \mathrm{PEF}<33 \% \\
\text { of predicted value, } 1 \text { silent chest, cyan osis, } \\
\text { exhaustion with poor respiratory effort, } \\
\text { confusion, maximal accessory muscle } \\
\text { use/recession, unable to talk, coma, } \\
\text { hypotension, marked tachycardia }\end{array}$ \\
\hline UK7 & 2018 & Local & Not specified & No & $\begin{array}{l}\text { Paediatric respiratory consultant, } \\
\text { paediatrician, paediatric medical } \\
\text { pharmacist }\end{array}$ & No & Three & $\begin{array}{l}\text { spO } 2<92 \% \text { plus any of the following: PEF }< \\
33 \% \text { of best or predicted, }{ }^{1} \text { silent chest, } \\
\text { cyanosis, poor respiratory effort, fatigue or } \\
\text { exhaustion, altered consciousness }\end{array}$ \\
\hline NL1a & 2019 & Local & $\mathrm{PICU}$ & No & Unspecified & No & Two $^{1}$ & Not specified \\
\hline NL1b & 2016 & Local & $\begin{array}{l}\text { Hospital, incl. } \\
\text { A\&E }\end{array}$ & No & $\begin{array}{l}\text { Paediatric respiratory } \\
\text { consultants, paediatrician, }\end{array}$ & No & Two $^{1}$ & $\mathrm{spO} 2 \leq 94 \%$ \\
\hline NL2 & 2017 & Local & $\begin{array}{l}\text { Hospital incl. } \\
\text { PICU }\end{array}$ & No & $\begin{array}{l}\text { Paediatrician, Paediatric } \\
\text { intensive care consultant, } \\
\text { paediatric respiratory consultant }\end{array}$ & No & Two $^{1}$ & $\mathrm{spO} 2 \leq 94 \%$ \\
\hline NL3 & Unknown & Local & $\begin{array}{l}\text { Hospital incl. } \\
\text { PICU }\end{array}$ & No & Paediatric respiratory consultant & No & Two $^{1}$ & $\mathrm{spO} 2 \leq 94 \%$ \\
\hline NL4 & 2017 & Local & $\mathrm{PICU}$ & No & Unspecified & No & Two $^{1}$ & $\mathrm{spO} 2 \leq 94 \%$ \\
\hline NL5 & \multicolumn{8}{|c|}{ Uses national $\mathrm{CPG}$} \\
\hline NL6 & Unknown & Local & Hospital & No & Unspecified & No & Two $^{1}$ & $\mathrm{spO} 2 \leq 94 \%$ \\
\hline NL7 & 2011 & Local & Hospital & No & $\begin{array}{l}\text { Paediatrician, paediatric } \\
\text { intensive care consultant }\end{array}$ & No & Two & $\mathrm{spO} 2 \leq 94 \%$ \\
\hline
\end{tabular}


medRxiv preprint doi: https://doi.org/10.1101/2021.09.20.21263735; this version posted September 23, 2021. The copyright holder for this preprint (which was not certified by peer review) is the author/funder, who has granted medRxiv a license to display the preprint in perpetuity. It is made available under a CC-BY 4.0 International license .

\section{Variation in drug choice, sequence and tone}

The recommended drug treatment pathways for each CPG are represented schematically in

Fig 1. Differences in drug choice, sequence and route of administration across the sampled CPGs were quantified in Table 2.

Fig 1. Variation across treatment pathways for most severe acute paediatric asthma across

British and Dutch CPGs. Drug recommendations proceed from left to right. Iv: intravenous, neb: nebulized. 


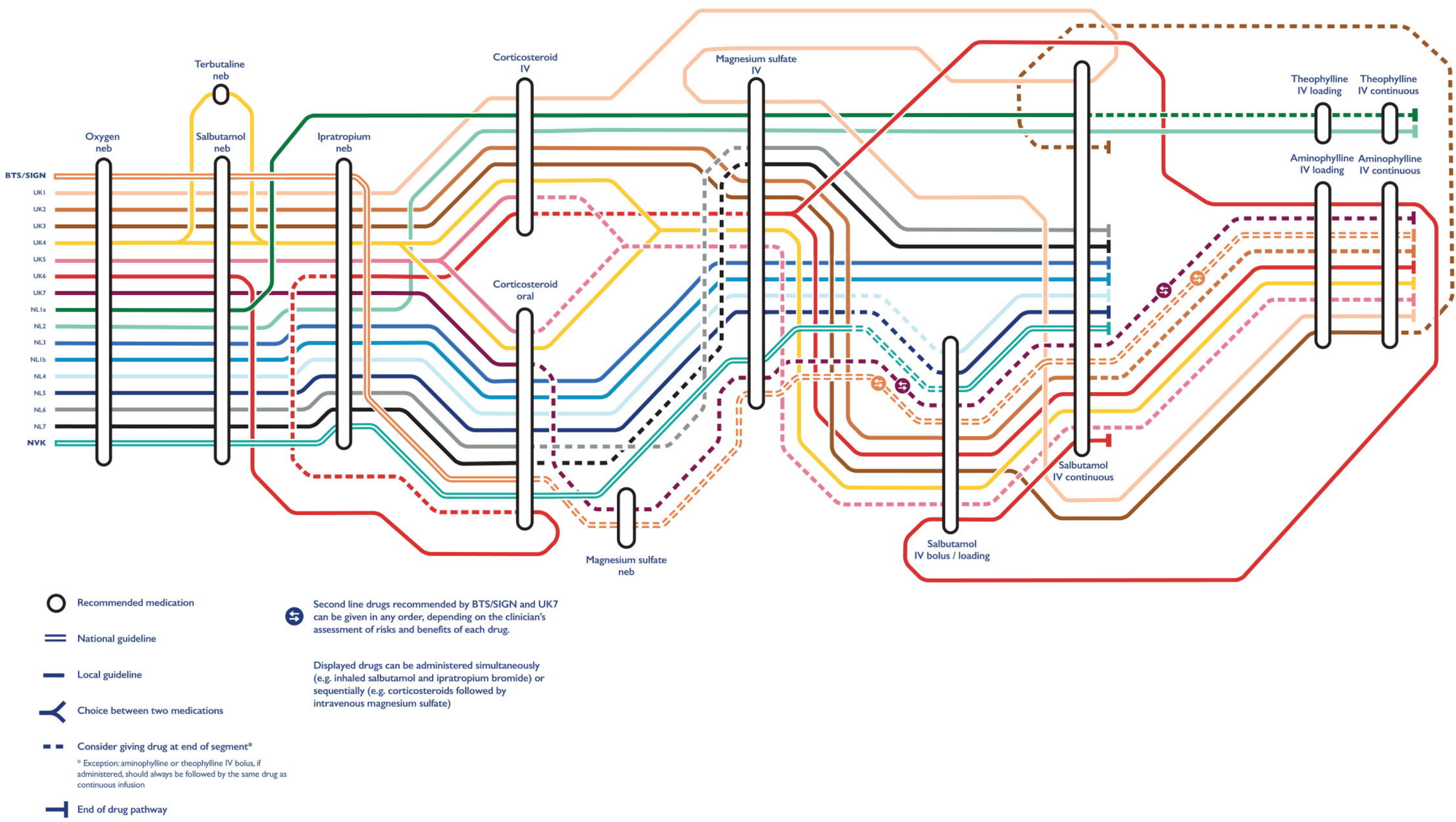


Table 2. Quantitative assessment of deviations from national guidance across sampled local British and Dutch CPGs. *: Local British guidelines received zero points at that position given the absence of a rigid sequence outlined by BTS/SIGN. O2: oxygen, CS: corticosteroids; MgSO4: magnesium sulfate.

\begin{tabular}{|c|c|c|c|c|c|c|c|c|c|c|c|}
\hline Step & Drug 1 & Drug 2 & Drug 3 & Drug 4 & Drug 5 & Drug 6 & Drug 7 & Drug 8 & \multicolumn{3}{|c|}{$\begin{array}{l}\text { Number of deviating steps across the loca } \\
\text { CPGs (\%) }\end{array}$} \\
\hline \multicolumn{12}{|c|}{ United Kingdom } \\
\hline BTS/SIGN & $\mathrm{O} 2$ & $\begin{array}{c}\text { Nebulized } \\
\text { salbutamol }\end{array}$ & $\begin{array}{c}\text { Nebulized } \\
\text { ipratropium }\end{array}$ & Oral CS & $\begin{array}{c}\text { Nebulized } \\
\text { MgSO4 }\end{array}$ & $\begin{array}{c}\text { Intravenous } \\
\text { MgSO4 }\end{array}$ & $\begin{array}{c}\text { Intravenous } \\
\text { salbutamol }\end{array}$ & $\begin{array}{c}\text { Intravenous } \\
\text { aminophylline }\end{array}$ & $\begin{array}{c}\text { First-line } \\
\text { drugs }\end{array}$ & $\begin{array}{c}\text { Second-line } \\
\text { drugs }\end{array}$ & $\begin{array}{c}\text { Across the } \\
\text { CPG }\end{array}$ \\
\hline UK1 & 0 & 0 & 0 & 1 & 1 & $0^{*}$ & $0^{*}$ & $0^{*}$ & $2(25 \%)$ & $0 *$ & $2(25 \%)$ \\
\hline UK2 & 0 & 0 & 0 & 1 & 1 & $0^{*}$ & $0^{*}$ & $0^{*}$ & $2(25 \%)$ & $0^{*}$ & $2(25 \%)$ \\
\hline UK3 & 0 & 0 & 0 & 0 & 1 & $0^{*}$ & $0^{*}$ & $0^{*}$ & $1(13 \%)$ & $0 *$ & $1(13 \%)$ \\
\hline UK4 & 0 & 1 & 0 & 1 & 1 & $0^{*}$ & $0^{*}$ & $0^{*}$ & 0 & $0^{*}$ & $3(38 \%)$ \\
\hline UK5 & 0 & 0 & 0 & 1 & 1 & $0^{*}$ & $0^{*}$ & $0^{*}$ & $2(25 \%)$ & $0^{*}$ & $2(25 \%)$ \\
\hline UK6 & 0 & 0 & 1 & 1 & 1 & $0^{*}$ & $0^{*}$ & $0^{*}$ & $3(38 \%)$ & $0^{*}$ & $3(38 \%)$ \\
\hline UK7 & 0 & 0 & 0 & 0 & 0 & $0^{*}$ & $0^{*}$ & $0^{*}$ & 0 & $0 *$ & 0 \\
\hline $\begin{array}{l}\text { No. of deviating } \\
\text { steps across local } \\
\text { British CPGs (\%) }\end{array}$ & 0 & $1(14 \%)$ & $1(14 \%)$ & $5(71 \%)$ & $6(86 \%)$ & 0 & 0 & 0 & $13(37 \%)$ & $0 *$ & $13(23 \%)$ \\
\hline \multicolumn{12}{|c|}{ Netherlands } \\
\hline NVK & $\mathrm{O} 2$ & $\begin{array}{l}\text { Nebulized } \\
\text { salbutamol }\end{array}$ & $\begin{array}{l}\text { Nebulized } \\
\text { ipratropium }\end{array}$ & Oral CS & None & $\begin{array}{l}\text { Intravenous } \\
\text { MgSO4 }\end{array}$ & $\begin{array}{l}\text { Intravenous } \\
\text { salbutamol }\end{array}$ & $\begin{array}{l}\text { No drug } \\
\text { recommended }\end{array}$ & $\begin{array}{l}\text { First-line } \\
\text { drugs }\end{array}$ & $\begin{array}{l}\text { Second-line } \\
\text { drugs }\end{array}$ & $\begin{array}{l}\text { Across the } \\
\text { CPG }\end{array}$ \\
\hline NL1a & 0 & 0 & 1 & 0 & - & 0 & 0 & 1 & $1(25 \%)$ & $1(33 \%)$ & $2(29 \%)$ \\
\hline NL1b & 0 & 0 & 0 & 0 & - & 0 & 0 & 0 & 0 & 0 & 0 \\
\hline NL2 & 0 & 0 & 0 & 1 & - & 0 & 0 & 1 & $1(25 \%)$ & $1(33 \%)$ & $2(29 \%)$ \\
\hline NL3 & 0 & 0 & 0 & 0 & - & 0 & 0 & 0 & 0 & 0 & 0 \\
\hline NL4 & 0 & 0 & 0 & 0 & - & 0 & 0 & 0 & 0 & 0 & 0 \\
\hline NL5 & 0 & 0 & 0 & 0 & - & 0 & 0 & 0 & 0 & 0 & 0 \\
\hline NL6 & 0 & 0 & 0 & 0 & - & 0 & 0 & 0 & 0 & 0 & 0 \\
\hline NL7 & 0 & 0 & 0 & 0 & - & 0 & 0 & 0 & 0 & 0 & 0 \\
\hline $\begin{array}{l}\text { No. of deviating } \\
\text { steps across local } \\
\text { Dutch CPGs (\%) }\end{array}$ & 0 & 0 & $1(14 \%)$ & $1(14 \%)$ & & 0 & 0 & $2(29 \%)$ & $2(6 \%)$ & $2(11 \%)$ & $4(8 \%)$ \\
\hline
\end{tabular}


medRxiv preprint doi: https://doi.org/10.1101/2021.09.20.21263735; this version posted September 23, 2021. The copyright holder for this preprint (which was not certified by peer review) is the author/funder, who has granted medRxiv a license to display the preprint in perpetuity.

It is made available under a CC-BY 4.0 International license .

The differences across nationally recommended pathways were examined. The NVK recommended six drugs in total, all of which were also recommended by BTS/SIGN. Alongside the drugs recommended by the NVK, BTS/SIGN also recommended nebulized magnesium sulfate and intravenous aminophylline. In both CPGs, the sequence and tone of recommendations differed more for second-line drugs than for first-line treatments. BTS/SIGN and the NVK recommended the same mandatory sequence of first-line treatments (oxygen, nebulized salbutamol, nebulized ipratropium bromide, oral corticosteroids) up to nebulized magnesium sulfate. The latter drug was advised as an optional treatment by British national guidance. National recommendations on second-line drugs diverged in both sequence and tone. While the NVK recommended considering intravenous magnesium sulfate before giving intravenous salbutamol, BTS/SIGN recommended that clinicians consider administering any of three recommended second-line drugs (intravenous magnesium sulfate, intravenous salbutamol and intravenous aminophylline) in the order they deemed most appropriate based on their assessment of the risks and benefits involved.

Local CPG recommendations for most severe APA were compared to the relevant national CPGs. All Dutch and British local CPGs aligned with their respective national CPG on four drugs. Three drugs were first-line treatments (oxygen, nebulized salbutamol, corticosteroids) and one was a second-line intervention (intravenous salbutamol). One British CPG (UK4) recommended nebulized terbutaline as an alternative for nebulized salbutamol without justifying this deviation from national guidance (see S1 on the local considerations behind various sequences of second-line treatments). Six out of seven local British CPGs departed from BTS/SIGN recommendations by omitting nebulized magnesium 
sulfate. None of them provided a rationale for this omission. Six Dutch local CPGs recommended the same drugs as the NVK. Differing with national recommendations, one Dutch local CPG omitted ipratropium bromide (NL1a), while two Dutch local CPGs included intravenous theophylline as their last recommended intervention (NL1a and NL2). These departures from national guidance were justified within the relevant local CPG.

Looking at the advised routes and methods of administration for recommended drugs, two Dutch and six British local CPGs deviated from national CPGs by recommending intravenous corticosteroids instead of, or following the administration of oral corticosteroids. A further two Dutch and six British local CPGs recommended a bolus of intravenous salbutamol before starting a continuous salbutamol infusion.

Apart from recommending nebulized terbutaline (UK4), and omitting nebulized magnesium sulfate (all CPGs but UK7), local British CPGs advised the same sequence of first-line drugs as BTS/SIGN. While they did not strictly differ from national guidance given the lack of a defined second-line drug sequence, local British CPGs, by contrast, recommended four distinct sequences of second-line treatments encompassing the same three drugs. The most common sequence was intravenous magnesium sulfate followed by intravenous salbutamol followed by intravenous aminophylline (UK2, UK4, UK5). By contrast, five out of seven local Dutch CPGs recommended the same treatment sequence as the NVK for both first-line and second-line drugs. 
Overall, local British CPGs deviated from the drug choice and order recommended in national guidance (where an order was declared) for $23 \%$ of their recommended interventions compared to $8 \%$ across local Dutch CPGs (see Table 2). Deviations from national guidance were more frequent for second-line treatments than for first-line drugs in Dutch local CPGs (11\% compared to $6 \%$ deviating steps). This was not the case in British local CPGs given the absence of a rigidly defined second-line drug sequence in BTS/SIGN guidance. Five local British CPGs and two Dutch local CPGs differed from their respective national CPG for multiple treatment steps. Local CPGs from both countries featured more variation in second-line interventions than first-line treatments.

Both Dutch and British local CPGs adopted a more flexible tone of recommendation for second-line interventions than for first-line drugs. This was especially true for British local CPGs. Local CPGs from both countries outlined more rigid drug sequences than national CPGs, with more drug recommendations communicated using an imperative tone ('give') and fewer alternatives provided.

\section{Variation in intravenous salbutamol dosage}

Recommended dose ranges for continuous salbutamol infusions across the sampled CPGs are shown in Fig 2. Both the recommended starting doses and maximum doses varied considerably across guidelines. Dutch CPGs advised significantly lower starting doses (in most cases $0.1 \mu \mathrm{g} / \mathrm{kg} / \mathrm{min})$ than British CPGs $(1-2 \mu \mathrm{g} / \mathrm{kg} / \mathrm{min})$ and allowed for higher maximum doses $(10 \mu \mathrm{g} / \mathrm{kg} / \mathrm{min})$, compared to British CPGs $(5-8 \mu \mathrm{g} / \mathrm{kg} / \mathrm{min})$. The salbutamol 
medRxiv preprint doi: https://doi.org/10.1101/2021.09.20.21263735; this version posted September 23, 2021. The copyright holder for this preprint (which was not certified by peer review) is the author/funder, who has granted medRxiv a license to display the preprint in perpetuity. It is made available under a CC-BY 4.0 International license .

dosages recommended in two of seven British local CPGs and six of seven Dutch local CPGs aligned with their respective national CPGs.

Fig 2. Recommended dose ranges for continuous salbutamol infusions across sampled CPGs from the UK and the Netherlands. Hatching indicates starting dose ranges. The arrow indicates the absence of a maximum dose recommended by the concerned guideline. UK2 and UK5: maximum doses calculated for a child of 10 kilograms based on the absolute maximum dosages recommended by each CPG. 


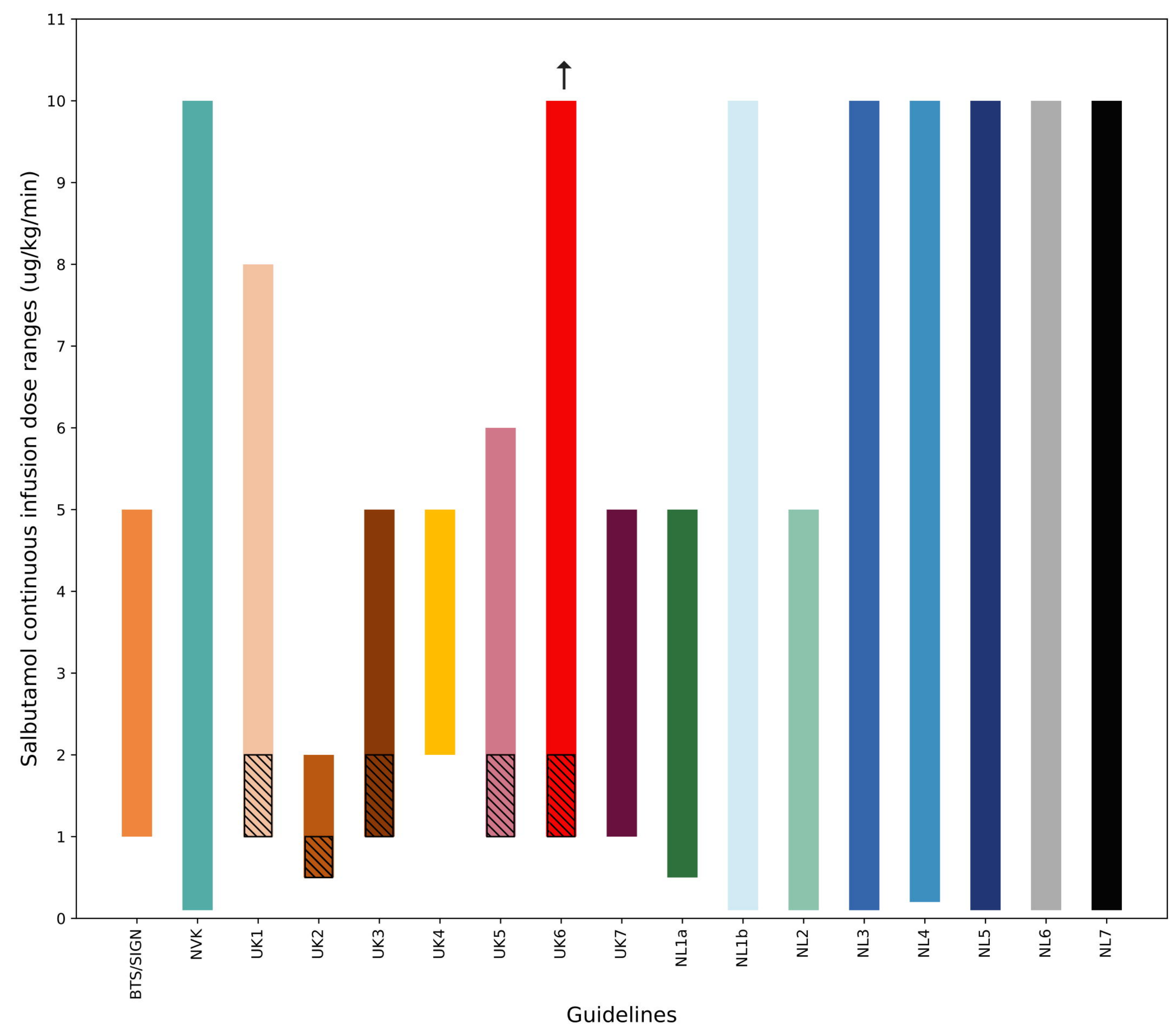




\section{Discussion}

This study demonstrated the presence of considerable variation across local CPGs from British and Dutch hospitals for the treatment of children with severe asthma, including numerous deviations from national guidance. Identified discrepancies included the choice, sequence and recommended methods of administration for the drugs advised for severe APA. Local recommendations for second-line drugs varied more than for first-line interventions, a finding that may reflect the paucity of evidence on effective treatments for severe APA (22). Differences were also observed in the tone of recommendations made by national CPGs based on this limited evidence. The high level of agreement between national CPGs and their mostly imperative tone on first-line drugs may reflect the ease with which the available evidence could be distilled into a single treatment pathway. Faced with less certain evidence on second-line interventions (32), Dutch national guidance recommended a rigid sequence of interventions while the British national guideline took a more permissive stance, describing various available treatment options without being prescriptive. Possibly as a result of these differences, local British CPGs deviated from national CPGs and from each other, more so than local Dutch CPGs. Substantial variation was also observed in recommended continuous salbutamol infusion rates. The presence of such variation between dosing regimens for one single drug suggests that variation across the sampled CPGs extends beyond the features measured in this analysis.

In the presence of multiple sources of clinical guidance $(10,33)$, local CPGs play a unique role in the translation and dissemination of evidence into local care (14). In contrast to national CPGs, which are often a careful summary of the best available evidence including all its 
uncertainties, the design of local CPGs caters to their use as direct guides for action by those clinicians with less experience and time to appraise evidence themselves as part of their decision-making $(34,35)$. As such, local CPGs ought to be immediately intelligible and implementable by these clinicians. This requires simplification of the detailed knowledge contained within national CPGs and the introduction of other sources of knowledge, including expert opinion, if evidence is lacking $(1,36,37)$. Given the slower cadence of national CPG development, and their focus on higher-grade evidence $(10,11)$, local CPGs may also constitute a preferred vehicle to incorporate new evidence alongside expert insights derived from local practice (16). The design of local CPGs, furthermore, entails adaptations in the recommendations of national CPGs in order to align with a hospital's resources, patient populations and working processes $(12,14)$.

Although the intended use of local CPGs may justify deviations from national guidance, some of the variation measured across the sampled local CPGs may not arise from a lack of evidence or the need to adapt national guidance to a given hospital setting $(12,38,39)$. The examined local CPGs, in fact, often failed to declare the methods by which they were produced, or to identify nor explain their deviations from national guidance. In the absence of justification such deviations may be considered a source of unwarranted variation in clinical care (38-40).

\section{Research and policy implications}

Variation in the treatment of APA, as other conditions, has been linked to poor clinical outcomes $(17,18,20)$. The extent to which this variation represents an appropriate adaptive 
response to local circumstances remains unknown. Despite this, research into the development of clinical guidelines has focussed on those authored by national bodies. This study highlights the need to further investigate the origins of variation between local CPGs and the effects of CPG variation on variation in clinical care.

While we recognise the need for different methods for national and local CPG development, the outcomes of these various approaches result in clinicians being faced with potential inconsistencies between national and local guidance. Consequently, where local guidelines deviate from national ones, appropriate flagging of and justification for these deviations should be provided to help clinicians navigate this inconsistency.

This study, furthermore, demonstrates that the treatment received by a child with acute asthma may be partly dictated by the hospital they present to. This widespread variation in the recommended treatment of a high-risk condition must be accompanied by open sharing of local CPGs. If excess harm arising from varying treatments for APA (amongst other conditions) is to be reduced, a culture of transparent, inter-organisational learning from local practice should be established. Alongside transparency of recommendations, the outcomes of local centres should be shared to enable the evaluation of the relationship between differences in treatment and differences in clinical outcomes. By sharing both local CPGs and outcomes data between providers, national bodies would be better informed of the use of these critical documents and clinicians would be better equipped to assess the potential benefits of variations to their practice. 
medRxiv preprint doi: https://doi.org/10.1101/2021.09.20.21263735; this version posted September 23, 2021. The copyright holder for this preprint (which was not certified by peer review) is the author/funder, who has granted medRxiv a license to display the preprint in perpetuity.

It is made available under a CC-BY 4.0 International license.

\section{Strengths and limitations}

In this study, we applied a novel methodology to analyse and represent variation across a type of clinical guidance that remains understudied. This method could be similarly applied to guidelines for other conditions. This study had several limitations. While the collected local CPGs stemmed from British and Dutch tertiary-level hospitals, the intended setting of use of local CPGs varied, for example, between emergency departments and critical care units. This may explain some of the variation that was measured. Whilst some of the identified differences may be assigned to these varied care settings, it is unlikely that the breadth of variation that was measured was attributable to setting alone. In order to represent variation in a legible way across numerous guidelines, differences across local CPGs were described with reference to their respective national guidance. This was done in the absence of a clearly established legal or customary hierarchy between national and local guidelines in the UK or in the Netherlands (41). Several local British CPGs were last updated prior to the publication of the version of British national guidance that was examined. This may explain some of the deviations that were found. Upon comparison however, the three most recent versions of BTS/SIGN guidance on asthma, published in 2014, 2016 and 2019, did not differ in their recommendations for treating most severe APA $(23,42,43)$. The analysis focused on a single treatment pathway, and did not encompass all grades of APA severity. The drug pathway for most severe APA was chosen as the most extensive drug sequence that could be compared across the sampled guidelines, including all available APA therapies up to maximal escalation. Although this pathway was associated with severity assessment parameters that did not fully align across guidelines, the chosen pathway ensured comparability across the sample for the sickest AP patients. Whereas this study 
medRxiv preprint doi: https://doi.org/10.1101/2021.09.20.21263735; this version posted September 23, 2021. The copyright holder for this preprint (which was not certified by peer review) is the author/funder, who has granted medRxiv a license to display the preprint in perpetuity. It is made available under a CC-BY 4.0 International license .

describes substantial variation across local CPGs and between local CPGs and their relevant national guidance, it does not explore the process by which this variation arises or the impact such variation has on clinical outcomes. Both questions are important areas for future work.

\section{Conclusions}

British and Dutch local CPGs varied substantially in their treatment recommendations for severe acute paediatric asthma. Although limited to a subset of guidelines, these findings may indicate the presence of considerable variation in local CPGs across medical conditions. Variation in local guidelines may contribute to variation of care more broadly and potentially undermine healthcare quality. 
medRxiv preprint doi: https://doi.org/10.1101/2021.09.20.21263735; this version posted September 23, 2021. The copyright holder for this preprint (which was not certified by peer review) is the author/funder, who has granted medRxiv a license to display the preprint in perpetuity.

It is made available under a CC-BY 4.0 International license .

\section{Acknowledgments}

The authors would like to acknowledge contribution of Melanie Wilson to data collection and Matthew Harrison to the depiction of data. This article is independent research supported by grants from the National Institute for Health Research (NIHR) Imperial Patient Safety and Translational Research Centre (PSTRC) PSTRC_2016_004. Infrastructure support for this work was provided by the NIHR Imperial Biomedical Research Centre (BRC) 121520013. JC acknowledges support from EPSRC grant EP/N014529/1 supporting the EPSRC Centre for Mathematics of Precision Healthcare and the Wellcome Trust 215938/Z/19/Z.

\section{Competing interests}

The authors declare no competing interests. 


\section{References}

1. Wolf JS, Hubbard H, Faraday MM, Forrest JB. Clinical practice guidelines to inform evidence-based clinical practice. World J Urol 2011;29;303-9.

2. Djulbegovic B, Guyatt GH. Progress in evidence-based medicine: a quarter century on. Lancet 2017;390:415-23.

3. Institute of Medicine (U.S.). Committee on Standards for Developing Trustworthy Clinical Practice Guidelines. Clinical practice guidelines we can trust [Internet]. Washington DC;2011[cited 2020 Jun 23]. 266 p. Report No: 978-0-309-16422-1. Available from: https://www.ncbi.nlm.nih.gov/books/NBK209539/.

4. Djulbegovic B, Hozo I, Dale W. Transforming clinical practice guidelines and clinical pathways into fast-and-frugal decision trees to improve clinical care strategies. J Eval Clin Pract 2018;24:1247-54.

5. Woolf SH, Grol R, Hutchinson A, Eccles M, Grimshaw J. Clinical guidelines. Potential benefits, limitations, and harms of clinical guidelines. BMJ 1999;318:527-30.

6. Algaze CA, Shin AY, Nather C, Elgin KH, Ramamoorthy C, Kamra K, et al. Applying Lessons from an Inaugural Clinical Pathway to Establish a Clinical Effectiveness Program. Pediatr Qual Saf 2018;3:e115.

7. Drummond M. Clinical Guidelines: A NICE Way to Introduce Cost-Effectiveness Considerations? Value Health 2016;19:525-30.

8. National Institute for Health and Care Excellence. How NICE clinical guidelines are 
developed: an overview for stakeholders, the public and the NHS [Internet]. London;2012[cited 2020 Jun 23]. 39 p. Available from:

https://www.nice.org.uk/process/pmg6/resources/how-nice-clinical-guidelines-aredeveloped-an-overview-for-stakeholders-the-public-and-the-nhs-pdf-3304422725317

9. Federatie Medisch Specialisten. Medisch-specialistische richtlijnen 2.0. [Internet]. Amsterdam;2012[cited 2020 Jun 23]. 82 p. Available from:

https://www.demedischspecialist.nl/sites/default/files/Medisch\%20specialistische\%2 Orichtlijnen\%202_0\%20okt\%202012.pdf

10. Kredo T, Bernhardsson S, Machingaidze S, Young T, Louw Q, Ochodo E, et al. Guide to clinical practice guidelines: The current state of play. Int J Qual Heal Care $2016 ; 28: 122-8$.

11. Balshem H, Helfand $M$, Schünemann HJ, Oxman AD, Kunz R, Brozek J, et al. GRADE guidelines: 3. Rating the quality of evidence. J Clin Epidemiol 2011;64:401-6.

12. Attia A. Adaptation of international evidence based clinical practice guidelines: The ADAPTE process. Middle East Fertil Soc J 2013;18:123-6.

13. World Heatlh Organization. Strong recommendations when the evidence is low quality [Internet]. Geneva;2014[cited 2020 Jun 23]. 13 p. Report No: 978924154896 0 . Available from:

https://www.who.int/publications/guidelines/Chp14_May2016.pdf?ua=1

14. Harrison MB, Légaré F, Graham ID, Fervers B. Adapting clinical practice guidelines to local context and assessing barriers to their use. Vol. 182, CMAJ 2010;182:e78-84.

15. Sniderman AD, Furberg CD. Why Guideline-Making Requires Reform. JAMA 2009;301:429-431. 
16. Schünemann HJ, Zhang Y, Oxman AD. Distinguishing opinion from evidence in guidelines. BMJ 2019;366:14606.

17. Corallo AN, Croxford R, Goodman DC, Bryan EL, Srivastava D, Stukel TA. A systematic review of medical practice variation in OECD countries. Health Policy 2014;114:5-14.

18. Kennedy PJ, Leathley CM, Hughes CF. Clinical practice variation. MJA 2010;193:S97-9.

19. Wijga AH, Kerkhof M, Gehring U, De jongste JC, Postma DS, Aalberse RC, et al. Cohort profile: The prevention and incidence of asthma and mite allergy (PIAMA) birth cohort. Int J Epidemiol 2014;43:527-35.

20. Levy ML, Andrews R, Buckingham R, Evans H, Francis C, Houston R, et al. Why asthma still kills: The National Review of Asthma Deaths (NRAD) [Internet]. Royal College of Physicians. London;2014[cited 2020 Jun 23]. 115 p. Report No: 978-1-86016-531-3. Available from: https://www.rcplondon.ac.uk/projects/outputs/why-asthma-still-kills

21. Nederlands Vereniging voor Kindergeneeskunde. Acuut astma bij kinderen. [Internet]. Amsterdam;2011. [cited 2020 Jun 23]. 154 p. Available from:

https://werkboeken.nvk.nl/Portals/0/richtlijnen/acuut\%20astma/Methodenacuutast ma.pdf

22. Babl FE, Sheriff N, Borland M, Acworth J, Neutze J, Krieser D, et al. Paediatric acute asthma management in Australia and New Zealand: Practice patterns in the context of clinical practice guidelines. Arch Dis Child 2008;93:307-12.

23. British Thoracic Society, Scottish Intercollegiate Guideline Network. British guideline on the management of asthma: A national clinical guideline. [Internet]. London;2019. [cited 2020 Jun 23]. 214 p. Report No. 158. Available from: https://www.sign.ac.uk/assets/sign158.pdf 
24. Asthma UK. The reality of asthma care in the UK: Annual Asthma Survey 2018 report. [Internet]. London;2018[cited 2020 Jun 23]. 30 p. Available from: https://www.asthma.org.uk/578f5bcf/globalassets/get-involved/external-affairscampaigns/publications/annual-asthma-care-survey/annual-asthma-survey2018/asthmauk-annual-asthma-survey-2018-v7.pdf

25. Bratton SL, Newth CJL, Zuppa AF, Moler FW, Meert KL, Berg RA, et al. Critical care for pediatric asthma: Wide care variability and challenges for study. Pediatr Crit Care Med 2012;13:407-14.

26. Tesse R, Borrelli G, Mongelli G, Mastrorilli V, Cardinale F. Treating pediatric asthma according guidelines. Front Pediatr 2018;6:1-7.

27. Gupta RP, Mukherjee M, Sheikh A, Strachan DP. Persistent variations in national asthma mortality, hospital admissions and prevalence by socioeconomic status and region in England. Thorax 2018;73:706-12.

28. Keeley D, Baxter N. Conflicting asthma guidelines cause confusion in primary care. BMJ 2018;360:k29.

29. Bray, Alison, Kampouraki, Emmanouela, Winter A. High Variability in Sepsis Guidelines in UK: Why Does It Matter? Int J Environ Res Public Health 2020;17:doi:10.3390/ijerph17062026.

30. Willis ZI, Duggan EM, Bucher BT, Pietsch JB, Milovancev M, Wharton W, et al. Effect of a clinical practice guideline for pediatric complicated appendicitis. JAMA Surg 2016;151:1-7.

31. Lyttle MD, O'Sullivan R, Doull I, Hartshorn S, Morris I, Powell CVE. Variation in treatment of acute childhood wheeze in emergency departments of the United 
Kingdom and Ireland: An international survey of clinician practice. Arch Dis Child $2015 ; 100: 121-5$.

32. Craig SS, Dalziel SR, Powell CVE, Graudins A, Babl FE, Lunny C. Interventions for escalation of therapy for acute exacerbations of asthma in children: An overview of Cochrane reviews. Paediatr Respir Rev. 2020.

33. Shekelle PG. Clinical practice guidelines what's next? JAMA 2018;320:757-8.

34. Manikam L, Hoy A, Fosker H, Wong MHY, Banerjee J, Lakhanpaul M, et al. What drives junior doctors to use clinical practice guidelines? A national cross-sectional survey of foundation doctors in England \& Wales. BMC Med Educ 2015;15:1-10.

35. Kastner M, Bhattacharyya O, Hayden L, Makarski J, Estey E, Durocher L, et al. Guideline uptake is influenced by six implementability domains for creating and communicating guidelines: A realist review. J Clin Epidemiol 2015;68:498-509.

36. Kashyap N, Dixon J, Michel G, Brandt C, Shiffman RN. GLIA GuideLine Implementability Appraisal v. 2.0. New Haven;2005[cited 2020 Jun 23]. 13 p. Available from: http://nutmeg.med.yale.edu/glia/doc/GLIA_v2.pdf

37. McCartney M. Making evidence based medicine work for individual patients. BMJ 2016;353:doi:10.1136/bmj.i2452.

38. Mercuri M, Gafni A. Medical practice variations: What the literature tells us (or does not) about what are warranted and unwarranted variations. J Eval Clin Pract 2011;17:671-7.

39. Sutherland K, Levesque JF. Unwarranted clinical variation in health care: Definitions and proposal of an analytic framework. J Eval Clin Pract 2020;26:687-96.

40. Atsma F, Elwyn G, Westert G. Understanding unwarranted variation in clinical 
practice: a focus on network effects, reflective medicine and learning health systems. Int J Qual Heal Care 2020;32:271

41. Metcalfe D, Pitkeathley C, Herring J. 'Advice, not orders'? The evolving legal status of clinical guidelines. J Med Ethics 2020;0:1-3.

42. Douglas G, Higgins B, Barnes N, Boyter A, Burge S, Cates C, et al. British guideline on the management of asthma: A national clinical guideline. [Internet]. London;2016. [cited 2021 Jan 21]. 214 p. Available from: https://www.britthoracic.org.uk/document-library/guidelines/asthma/btssign-asthma-guideline-2016/

43. British Thoracic Society Scottish Intercollegiate Guideline Network. British guideline on the management of asthma: A national guideline.[Internet]. London;2016. [cited 2021 Jan 21]. 196 p. Available from: https://www.brit-thoracic.org.uk/documentlibrary/guidelines/asthma/btssign-asthma-guideline-2014/

\section{Supporting information}

S1 Table. Evidence and considerations outlined for second-line APA drug recommendations in sampled local British and Dutch CPGs. Evidence grades are assigned based on a standardized BTS/SIGN methodology. 